\title{
Evaluating the Analgesic Efficacy of Solanum surattense (Herbal Seed Extract) in Relieving Pulpal Pain - An In-vivo Study
}

\author{
Vijay Amirtharaj L*, Srinivasan N, Sireesha Abburi, Karthikeyan K and Mahalaxmi S \\ Department of Conservative Dentistry and Endodontics, SRM Dental College, SRM University, Ramapuram, Chennai-89, Tamil Nadu, India
}

\begin{abstract}
Solanum surattense has been largely used in the indigenous system of medicine for various therapeutic effects, mainly analgesics. The aim of the present study was to assess the analgesic effect of the ethanolic extract of the powdered seeds of Solanum surattense in relieving pulpal pain. Patients reporting with pain to the department of conservative dentistry and endodontics, SRM dental college and diagnosed with symptomatic irreversible pulpitis were selected for this study. Ethical committee approval from Institutional Review Board and informed consent from the patients were obtained. The intensity of pain was recorded using Heft Parker Visual Analogue Scale (HP-VAS). Patient was asked to rinse the experimental solution for 3 minutes. The intensity of pain was again recorded using HP-VAS scale. Results showed $68 \%$ reduction of pulpal pain in the experimental group. Thus it can be concluded that Solanum surattense when used as an oral rinse showed considerable analgesic activity immediately after its usage. It can be thus safely used as an alternative emergency drug to relieve pulpal pain in symptomatic patients.
\end{abstract}

Keywords: Solanum surattense; Herbal extract; Irreversible pulpitis; Pulpal pain; HP- VAS

\section{Introduction}

Herbs have been used for centuries to prevent and control disease [1]. Herbal extracts are effective because they interact with specific chemical receptors within the body, and in a pharmacodynamic sense, drugs themselves [2]. It may be considered as good adjuncts and/or alternatives to treatment for oral problems as they have minimal or no side effects [2].

Solanum surattense Burm.f. (Family Solanaceae) is a very prickly, perennial, diffuse, patch forming herb, flowering and fruiting throughout the year. It is commonly found in Southeast Asia, Malaysia, Australia and in all districts of Tamil Nadu, India [3]. This plant is also known as "Yellow berried night shade/ Indian night shade" in English [4], Kandangathiri/ Kantakari in Tamil and Kateli/ Berkateli in Hindi. All parts of the plant, such as stem, flowers, fruits and roots have medicinal properties. In India, entire dried plant is used for treating leprosy, dropsy and cough [5]. Pharmacological activities such as antibacterial, antifungal, antinociceptive, antioxidant, hypoglycemic and larvicidal properties have been associated with this plant [6].

Pandey et al. has reported that the seed fumes of this plant were useful in the treatment of tooth pain and pain from gingival swellings. He also stated that it was found to relieve fever, rheumatism, pneumonia and other respiratory troubles [7]. Its antibacterial activity was also detected against S.aureus, Streptococcus spp, E.coli etc. [8].

However, so far there are no studies in dental literature on the effect of this herb in relieving pulpal pain. Hence, the aim of this study was to evaluate the analgesic efficacy of seed powder of S. surattense in relieving pulpal pain when used as mouthwash in patients with symptomatic irreversible pulpitis.

\section{Materials and Methods}

The study was presented before the Institutional Review Board of SRM University and approval was obtained.

\section{Experimental mouthrinse preparation}

Powdered dried seeds of Solanum surattense was obtained commercially (R.R Herbs, Seven hills, Chennai). $5 \mathrm{~g}$ of $S$. surattense powder was mixed with $50 \mathrm{ml}$ of distilled water and the mixture was stirred for about 10 seconds to form $10 \%$ solution.

Patients reporting to the department of Conservative Dentistry and Endodontics with tooth pain and diagnosed with symptomatic irreversible pulpitis, were included in this study. Patients were explained about the procedure and informed consent was obtained. Teeth with wide open cavities and frank pulpal exposure having moderate to intense pain HP-VAS [9] readings from 85-144 mm were included in the study. Patients with systemic diseases under medication and/or under the influence of alcohol were excluded from the study. A total of fifty patients, divided randomly into two groups of 25 each (experimental and placebo) using simple randomization procedure (sealed envelopes) were involved in the study (Figure 1).

The intensity of pain was recorded using HP-VAS [9] before the procedure was initiated. The patient was asked to hold the freshly prepared herbal solution in the mouth for about two minutes and then rinse for a minute. Coloured distilled water served as control. The intensity of pain after rinsing was again recorded using HP-VAS [9] scale.

The HP-VAS [9] scores were tabulated. The data showed normal distribution and analysed statistically using paired (Intra group comparison) and unpaired ' $t$ ' tests (Inter group comparison) at $5 \%$ significance.

\section{Results}

In this preliminary study, the test results showed that $68 \%$ of the

*Corresponding author: Vijay Amirtharaj L, Sr.Lecturer, Department of Conservative Dentistry and Endodontics, SRM Dental College, SRM University, Ramapuram, Bharathi Salai, Ramapuram, Chennai-89, Tamil Nadu, India, Tel: +919884111167; E-mail: vijuendo@yahoo.co.in

Received January 31, 2015; Accepted March 09, 2015; Published March 12 2015

Citation: Vijay Amirtharaj L, Srinivasan N, Sireesha Abburi, Karthikeyan K Mahalaxmi S (2015) Evaluating the Analgesic Efficacy of Solanum surattense (Herbal Seed Extract) in Relieving Pulpal Pain - An In-vivo Study. Dentistry 5: 288. doi:10.4172/2161-1122.1000288

Copyright: () 2015 Vijay Amirtharaj L, et al. This is an open-access article distributed under the terms of the Creative Commons Attribution License, which permits unrestricted use, distribution, and reproduction in any medium, provided the original author and source are credited. 


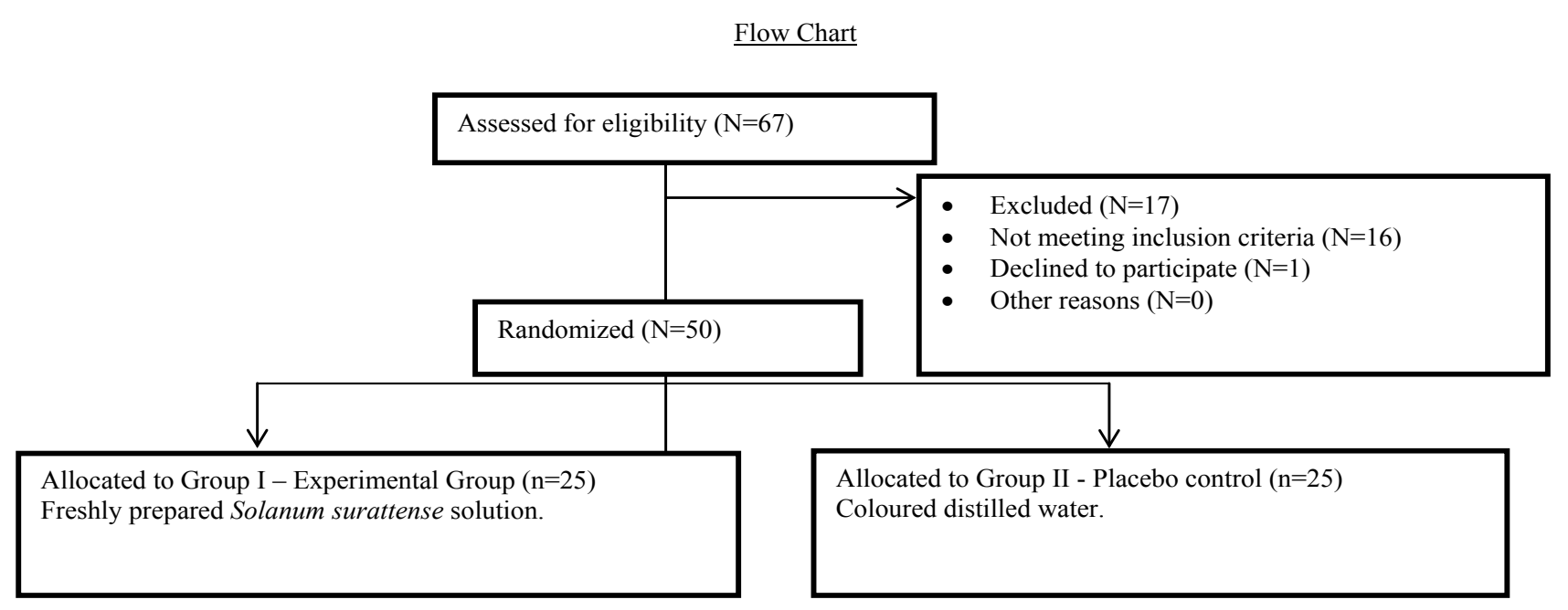

Figure 1: Flow chart of the in-vivo study.

\begin{tabular}{|c|c|c|c|c|c|c|}
\hline \multirow[b]{2}{*}{$\begin{array}{l}\text { Intensity of pain } \\
\text { (HP-VAS Scale) mm }\end{array}$} & \multicolumn{3}{|c|}{ Experimental Group } & \multicolumn{3}{|c|}{ Placebo Group } \\
\hline & Total (25 Subjects) & Reduction of pain & No reduction of pain & Total (25 Subjects) & Reduction of pain & No reduction of pain \\
\hline Moderate(85 mm) & 11 & $8(32 \%)$ & $3(12 \%)$ & 13 & $4(16 \%)$ & $9(36 \%)$ \\
\hline Severe(114 mm) & 11 & $8(32 \%)$ & $3(12 \%)$ & 7 & $3(12 \%)$ & $4(16 \%)$ \\
\hline Intense(144 mm) & 3 & $2(8 \%)$ & $1(4 \%)$ & 5 & $3(12 \%)$ & $2(8 \%)$ \\
\hline Percentage Total & $100 \%$ & $68 \%$ & $32 \%$ & $100 \%$ & $40 \%$ & $60 \%$ \\
\hline
\end{tabular}

Table 1: Comparison of post rinse percentage reduction of pain in subjects of experimental and placebo groups.

\begin{tabular}{|c|c|c|c|}
\hline \multicolumn{2}{|c|}{ Groups } & Mean $(\mathrm{mm})$ & SD \\
\hline \multirow{2}{*}{ Experimental Group } & Pre-rinse & 107.32 & 18.814 \\
\cline { 2 - 4 } & Post-rinse & 65.36 & 29.203 \\
\hline Placebo Group & Pre-rinse & 104.76 & 17.709 \\
\cline { 2 - 4 } & Post-rinse & 82.52 & 25.878 \\
\hline
\end{tabular}

Table 2: Comparison of pre and post rinse VAS Scores of Experimental and Placebo Groups.

patients in the experimental group had pain relief after usage of the experimental mouth rinse (Table 1). There was no statistical significance in the initial HP-VAS [9] scores between the two groups (Unpaired ' $\mathrm{t}$ ' test). When comparing the VAS scores of pre and post-rinse within each group (Paired ' $t$ ' test), high level of significance was observed at $\mathrm{p}=0.000$ (Table 2). A significant difference was also observed in the post-rinse VAS scores between the placebo and Solanum surattense groups ( $\mathrm{p}=0.0327$ Unpaired ' $\mathrm{t}$ ' test).

\section{Discussion}

Pain is an unpleasant sensory and emotional experience associated with actual or potential tissue damage, or described in terms of such damage [10].Pain is a subjective, unpleasant, physical and psychological experience observed as a result of the stimulation of identifiable nerve fibers with defined pathways to the brain via the spinal cord. Pain often results from tissue damage that stimulates nociceptive receptors (nociceptive pain).

Oral mucosal drug delivery is an alternative route to systemic drug delivery that offers several advantages over both injectable and enteral routes [11]. Oral mucosa offers excellent accessibility and is a more acceptable route to the patient [12]. The present study aimed at investigating the analgesic efficacy of S. surattense seed powder in relieving pulpal pain when used as mouthrinse in patients with symptomatic irreversible pulpitis.

Preliminary phytochemical studies on Solanum species have resulted in isolation of many steroidal saponins and steroidal alkaloid saponins, with various pharmacological activities [13,14]. Solanum surattense has been reported to have a number of alkaloids $[15,16]$, sterols [17], saponins [18], flavonoids and their glycosides [19] tannins, gums [8]. It is most likely that the components of the extract might induce analgesia like NSAIDs, by inhibiting the production and release of prostaglandins or blocking their receptors [20,21].

It is often combined with NSAIDS and opioids for the management of moderate to severe pain. Alkaloids have been found to be responsible for both analgesic and anti-inflammatory actions. In berries of Solanum, highest amount of the flavonoid solasodine $(5 \mathrm{~g} / \mathrm{kg})$ is present [22]. Flavonoids are known to interact with the cyclooxygenase system, so as to interfere with arachidonic acid synthesis and inhibit the production of prostaglandins which are involved in the late phase of acute inflammation and pain perception [23]. Other mechanism by which flavonoids reduce pain perception was due to its free radical scavenging activity as these free radicals are involved during pain stimulation [24]. Also, there are few reports in the role of tannins and 
Citation: Vijay Amirtharaj L, Srinivasan N, Sireesha Abburi, Karthikeyan K, Mahalaxmi S (2015) Evaluating the Analgesic Efficacy of Solanum surattense (Herbal Seed Extract) in Relieving Pulpal Pain - An In-vivo Study. Dentistry 5: 288. doi:10.4172/2161-1122.1000288

Page 3 of 3

saponins in anti-nociceptive and anti-inflammatory actions. Saponins have also been reported to inhibit histamine release in-vitro [25].

In this study the experimental mouthrinse solution showed significantly better results than the control group. Solanum surattense when used as an oral rinse showed considerable analgesic activity immediately after its usage. This may be because the oral mucosa is highly vascularized and it is relatively permeable. So drugs that are absorbed through the oral mucosa directly enter the systemic circulation, bypassing the gastrointestinal tract and first-pass metabolism in the liver [26]. The mucosa of the soft palate, the sublingual, and the buccal regions are non-keratinized and it constitutes to about $60 \%$ of the total surface area of the oral lining [27]. The amount of absorption depends on the relative thickness and degree of keratinization of tissues [26].

The limitation of this preliminary study are the non-inclusion of age, gender and duration of pain relief The results of this preliminary study thus suggest that Solanum surattense seed extract can be safely used as an emergency alternative mouth rinse to relieve pain in symptomatic patients. However, further studies are needed in order to understand the precise mechanism of action and also to assess the purified fractions of Solanum surattense seed extract for pharmacological and toxicological characterization in the dental pulp.

\section{Conclusion}

Within the limitations of this preliminary study, it can be concluded that the seed powder of $S$. surattense can be used as a safe adjunct to other methods in relieving pulpal pain when used as mouthwash in patients with symptomatic irreversible pulpitis.

\section{References}

1. Bent S, Ko R (2004) Commonly used herbal medicines in the United States: a review. Am J Med 116: 478-485.

2. Taheri JB, Azimi S, Rafieian N, Zanjani HA (2011) Herbs in dentistry. Int Dent J 61: 287-296

3. Mathew KM (1983) The Flora of the Tamil Nadu Carnatic, Vol.III, Part I \& II, The Rapinat Herbarium, St. Joseph's College, Tiruchirapalli, India, 1061-1064.

4. Kirthikar KR, Basu BD (1975) Indian Medicinal Plants. Bishensingh, Mahendra Pal Singh Publishers, Dehradun 2: 872.

5. Singh MP, Malla SB, Rajbhandari SB, Manandhar A (1979) Medicinal plants of Nepal - Retrospects and Prospects. Economic Botany 33: 185-198.

6. Prempeh ABA, Mensah-Attipoe J (2008) Analgesic activity of crude aqueous extract of the root bark of Zanthoxylum Xanthoxyloides. Ghana Med J 42: 7984.

7. Pandey HP (2004) Seed fume of Solanum surattense: A traditional panacea for teeth and gums. Indian Journal of Traditional Knowledge 3: 206-207.

8. Sheeba E (2010) Antibacterial activity of Solanum surattense Burm. F. Kathmandu university journal of science, engineering and technology 6: 1-4.

9. Heft MW, Parker SR (1984) An experimental basis for revising the graphic rating scale for pain. Pain 19: 153-161.
10. Mersky H (1979) Pain terms: a list with definitions and notes on usage. Recommended by the IASP Subcommittee on Taxonomy. Pain 6: 249.

11. Shojaei $A H$ (1998) Buccal mucosa as a route for systemic drug delivery: a review. J Pharm Pharm Sci 1: 15-30.

12. Merkle HP, Andes R, Sandow J, Schurr W. Drug delivery of peptides: the buccal route. Delivery Systems for Peptide Drugs, Davis SS, llium L, Tomlinson E, Eds., Plenum Press, New York, 159.

13. Shahiladevi S, Jayanthi G, Jegadeesan M (2006) Preliminary phytochemical studies on Solanum surattense burm.f. Seeds. Anc Sci Life 26: 59-64.

14. Lu Y, Luo J, Kong $L$ (2011) Steroidal alkaloid saponins and steroidal saponins from Solanum surattense. Phytochemistry 72: 668-673.

15. Siddiqui S, Faizi S (1983) Studies in the chemical constituents of the fresh berries of Solanum xanthocarpum. Journal of Chemical Society of Pakistan, 5: 99-101.

16. Manjunath BL, Shadaksharaswamy M (1942) Reexamination of the alkaloids of the fruits of Solanum xanthocarpum. Journal of Mysore University 3B:117-121.

17. Kusano G, Beisler J, Sato $Y$ (1973) Steroidal constituents of Solanum xanthocarpum. Phytochemistry 12: 397-401.

18. Tupkari SV, Saoji AN, Deshmukh VK (1972) Phytochemical study of Solanum xanthocarpum. Planta Med 22: 184-187.

19. Debey P, Gupta PC (1936) A new flavonol glycosides from the flowers of Solanum xanthocarpum. Phytochemistry 17: 613.

20. Sawadogo WR, Boly R, Lompo M (2006) Anti-inflammatory, analgesic and antipyretic activities of Diclipteraverticillata. International Journal of Pharmacology 2: 435-438.

21. Kaushik D, Kumar A, Kaushik P, Rana AC (2012) Analgesic and AntiInflammatory Activity of Pinus roxburghii Sarg. Adv Pharmacol Sci 2012: 245431.

22. Gawande A, Wankhade S, Shankhopal KV, Shinde GB (1991) Isolation, purification and characterization of solasodine - A Steroidal alkaloid from Solanum surattense berries. Indian Drugs 28: 149-150.

23. Dubois RN, Abramson SB, Crofford L, Gupta RA, Simon LS, et al. (1998) Cyclooxygenase in biology and disease. FASEB J 12: 1063-1073.

24. Kim HK, Park SK, Zhou JL, Taglialatela G, Chung K, et al. (2004) Reactive oxygen species (ROS) play an important role in a rat model of neuropathic pain. Pain 111: 116-124.

25. Adeyemi OO, Adeneye AA, Alabi TE (2011) Analgesic activity of the aqueous seed extract of Hunteria umbellata (K. Schum.) Hallier f. in rodents. Indian J Exp Biol 49: 698-703.

26. Squier CA (1991) The permeability of oral mucosa. Crit Rev Oral Biol Med 2 13-32.

27. Squier CA, Kremer MJ (2001) Biology of oral mucosa and esophagus. J Natl Cancer Inst Monogr 7-15. 